\title{
CONSUMER CONTRACT GOVERNANCE IN A DEREGULATING JAPAN
}

Veronica Taylor

This article analyses patterns of governance - how public and private policy networks are managed - in consumer contracts in a deregulating Japan. It outlines the structure of Japan's service industry and consumer problems, before considering the framework for juridical intervention, bureaucratic regulation and pressures for further legislative activity. As the question of how to curb excesses of power in a deregulated environment governed by multiple agents becomes more acute, consumer governance seems likely to change, and with it the utility of current theories of how law operates in Japan.

\section{INTRODUCTION}

The overarching question for most industrialised economies at the end of the twentieth century is: who governs? In many areas the answer frequently seems to be not the nation state, but the new economic sovereign - the corporation. The welfare state is in retreat, partly because neoclassical economic ideology is in the ascendancy and partly in pragmatic recognition that the cost of maintaining many state regulatory functions in mature or stagnating economies is often unacceptably high. ${ }^{1}$ But reports of the death of the nation state are also exaggerated. National governments remain the only institutions able to effectively monitor corporations and to regulate formally, both to correct for market imperfections and to protect citizens from market excesses and abuse. The significant change is not so much the hollowing out of the state, but the emergence of its new role in managing interorganizational networks and expanding its repertoire of governance.

* Senior Lecturer, Faculty of Law; Associate Director, Asian Law Centre, University of Melbourne.

1 See V Taylor "Global Access to Deregulated Markets in Asia: Is Competition Policy the Key?" OECD, Regulatory Reform and International Market Openness (OECD, Paris, 1996) 233. 
This essay considers the governance of consumer transactions in Japan. Governance, of course, now has multiple definitions. ${ }^{2}$ Here it is used in the sense of the way in which public and private policy networks are managed. There is extensive literature surveying state control of industry in Japan and the role of the bureaucracy in forming and applying regulatory policy, which is not reviewed here. This essay has a more modest aim; to canvass some of the regulatory questions surrounding the operation of consumer contracts in contemporary Japan, and to consider the extent to which the lines of parallel governance are likely to be redrawn in a deregulatory climate.

Consumer contracts provide a useful setting for examining legal and administrative policy in Japan in the late 1990s, in part because Japanese attention to consumer protection lags behind developments in the EU, Australia and New Zealand. As the Japanese service sector grows, demands for enhanced consumer protection threaten to collide with other policy network interests. ${ }^{3}$ One of the motifs of the new governance debate in Japan is deregulation - although the promised program of changes has now been handballed through four administrations. Running counter to the deregulatory push is the determination among many bureaucrats not to cede control of regulatory jurisdictions. Current patterns of governance in consumer transactions thus reveal a range of conflicting ideas about contractual practice in Japan which may qualify some of the received wisdom about Japanese law and its relationship to business.

Microeconomic analysis has tended to dominate writing on Japanese commercial relationships in the 1980s and 1990s, arguing that Japan has a form of alliance (or strategic) capitalism that nurtures long-term, hierarchical relationships between corporations and individuals, in which implicit agreements are made and enforced without recourse to law. ${ }^{4}$ Frequently cited examples include the relationships between manufacturer and parts supplier, where continuing contracts function as proxies for vertical integration ${ }^{5}$

2 Including the minimal state; corporate governance; the new public management; "good governance"; governance as a sociocybernetic system; and as self organising network: see $\mathrm{R}$ Rhodes "The New Governance: Governing without Government" (1996) XLIV Political Studies 652. See also O Williamson The Mechanisms of Governance (OUP, Oxford, 1996).

3 M Atkinson and Coleman "Policy Networks, Police Communities and the Problems of Governance" (1992) 5 Governance: An International Journal of Policy and Administration 154.

4 M Gerlach Alliance Capitalism (University of California Press, Berkeley, 1992).

5 See eg M Smitka Competitive Ties: Subcontracting in the Japanese Automotive Industry (New York, Columbia University Press, 1991); B Asanuma "Japanese Manufacturer-Supplier Relationships in International Perspective: The Automobile Case" in P Sheard (ed) International Adjustment and the Japanese Firm (Allen and Unwin, Sydney, 1992) 99; M Itoh "Organizational Transactions and Access to the Japanese Import Market" in P Sheard (ed), above, 50. 
and assist adaptation to changes in competitive conditions. ${ }^{6}$ One of the questions which remains unexplored is whether long-term or continuing consumer contracts in Japan can be readily fitted within this explanatory framework.

Very little legal writing in English directly contests the microeconomic vision of Japanese transacting patterns. Classical treatises describe the anatomy of the Civil and Commercial Codes and special laws. ${ }^{7}$ A popular, but dated, counterpart literature describes the cultural uniqueness of Japanese contracts in action. In the latter genre, the civil law, the judiciary and legal services are depicted as irrelevant for commercial actors, who prefer to order their relationships through informal means. Contract litigation is rare, it is claimed, because the Japanese have a cultural aversion to litigation. ${ }^{8}$ More recent arguments are that contract litigation is made inaccessible by government and bureaucratic elites who view public commercial litigation as socially destabilising, ${ }^{9}$ or that the Japanese are also rational actors who can - and do - bargain in the shadow of the law. ${ }^{10}$ More recent work on judicial responses to contract disputes qualifies the received wisdom by pointing to the significance of the courts and judicial intervention as a valve for both escaping and adjusting continuing contractual ties. ${ }^{11}$ There is, however, a striking absence of empirical data informing legal scholarship in English about Japanese commercial contracts and quasi-

6 Sheard, above $\mathrm{n} 5$.

7 See eg Z Kitagawa Doing Business in Japan (Matthew Bender, New York, looseleaf); H Oda Japanese Law (Butterworths, London, 1992).

8 See eg T Kawashima (1967) Nihonjin no Ho Ishiki [The Legal Consciousness of the Japanese] (1967); T Kawashima (C Stevens trans) "Contract Consciousness of the Japanese" (1974) 7 Law in Japan 1; T Kawashima "Dispute Resolution in Contemporary Japan" in A von Mehren (ed) Law in Japan: The Legal Order in a Changing Society (Harvard UP, Cambridge Mass, 1963) 41. See also the extracts on contracting in Y Yanagida et al (eds) Law and Investment in Japan: Cases and Materials (Harvard University Press; Cambridge Mass, 1994); N Kashiwagi and A Zaloom "Contract Law and the Japanese Negotiation Process" in G McAlinn (ed) The Business Guide to Japan (Reed Publishing, Singapore, 1996) 85.

9 J Haley Authority Without Power: Law and the Japanese Paradox (OUP, Oxford, 1992).

10 See eg J M Ramseyer "Reluctant Litigant Revisited: Rationality and Disputes in Japan" (1988) 14 Journal of Japanese Studies 112.

11 T Uchida Keiyaku no saisei [The Rebirth of Contract] (Kobundo, Tokyo, 1990); G Rahn Rechtsdenken und Rechtsauffassung in Japan [Legal Thought and the Conception of Law in Japan] (C H Beck, München, 1990); V Taylor 'Continuing Transactions and Persistent Myths: Contracts in Contemporary Japan' (1993) 19 MULR 352. 
contractual relationships. ${ }^{12}$ This gap will begin to close once the results of a number of current projects are published. ${ }^{13}$

In the meantime, it may be useful to reassess the way in which Japanese contracting has been framed to date. The microeconomic preoccupation with horizontal and vertical commercial ties has tended to obscure the scope and variety of contract types within the Japanese economy. For the most part, the contractual relationship is depicted as a neoclassical binary exchange, embedded in the broader cultural milieu of the parties' identities and the industry setting. When a dispute arises between two commercial actors, they either ignore the default rules furnished by law and bargain in its shadow, or - much less frequently - they, invoke legal rules through litigation. These representations reinforce the dualism of a contract model in which the parties' transactional norms (and/or industry practices) are expected to diverge from legal rules. Alternatively Japanese contracts are viewed along the axis of the state as regulator of individual corporations, a key example being the progressive expansion of the Japan Fair Trade Commission and the impact of the Anti-Moncpoly Law in the 1990s on vertical and horizontal transactional relationships. ${ }^{14}$

The problem with these trajectories for viewing Japanese contracts is that they are overly simplistic. In Japan, as in Australia and New Zealand, contractual relationships are shaped and regulated on multiple levels, by multiple agents. As Macaulay and others have pointed out, contract relationships are formed and performed through the processes of governance, within a matrix comprising the contract parties (their employees, relationship and relative economic leverage); the structure of the industry (schemes of self regulation, bureaucratic directives and guidance); cultural mores and ideology; formal legal rules; court generated norms; and intervention by third parties such as government inspectors, bankers and lawyers. ${ }^{15}$

12 But cf R Dore Flexible Rigidities: Industrial Policy and Structural Adjustment in the Japanese Economy 1970-1980 (The Athlone Press, London, 1986).

13 Preliminary results from one project include: M Kato "Nihonjin no keiyakukan [Japanese Attitudes to Contracts]" (1996) 1096 Jurisuto 44. See also L Nottage "Economic Dislocation and Contract Renegotiation in New Zealand and Japan: A Preliminary Empirical Study" (1997) 27 VUWLR 59.

14 Law No 54, 1947. See K Sanekata and S Wilks, "The Fair Trade Commission and the Enforcement of Competition Policy In Japan" in Doern and Wilks (eds) Comparative Competition Policy (Clarendon Press, Oxford, 1996) 139.

15 S Macaulay "Long-Term Continuing Relations: The Amercian Experience Regulating Dealerships and Franchises" in C Joerges (ed) Franchising the Law: Theoretical and Comparative Approaches in Europe and the United States (Nomos Verlagsgesellschaft, Baden-Baden, 1991) 179. Of the current theoretical studies of law in Japan, F Upham Law and Society in Postwar Japan (Harvard UP, 
This broader picture of contract governance is important. At a basic empirical level it should lift our focus beyond the stasis of many existing doctrinal and cultural descriptions. In particular, it should enable us to gauge the extent to which economic change acts as a catalyst for shifts in contract design and their legal regulation. In a period of intense globalisation this is significant because the legal responses to global economic expansion and restructuring are local and often culturally specific. A more nuanced picture of the operation and regulation of contracts in Japan is a prerequisite for meaningful comparisons, but also potentially important because of the way in which Japan is viewed as a model for legal reforms and development in developing economies such as Indonesia and Vietnam.

\section{THE OTHER JAPANESE ECONOMY: SMALL AND MEDIUM SIZED SERVICE ENTERPRISES}

More and more of the incidents of daily life are being regulated by contracts with private corporations. Personal freedom is increasingly delimited, not by state regulation but by corporate controls on access to education and technical qualifications; eligibility for credit cards, loans and financial products; control of data about personal details and consumption patterns. The state, too, is progressively vacating provision of other social goods such as public safety (eg the rise of private policing) ${ }^{16}$; labour market protections (eg abandonment of centralized wage bargaining and instituionalised unionism); and the supply of basic commodities (eg privatisation of public utilities). In Japan, as elsewhere, consumer transactions are one of the frontlines in the realignment of the new economic order.

Some of these changes are reflected in the growth of the domestic and export service sectors of mature industrialised economies. Typically, new consumer services take the form of standardized contracts of adhesion which extend over time. For lawyers and public policy makers in the EU, North America, Australia and New Zealand, the question for much of the 1970s and 1980s was how to balance the tension between contract welfarism and market capitalism: whether the state should defer to the demands of neoclassical economics and treat these transactions as planned risk allocation between rational actors, or whether it should intervene to monitor the corporate morality of contract creation, performance and dispute resolution. State intervention was assumed to be either specialised legislation covering an industry sector or type of problem, or judicial responses to the small number of litigated consumer cases. In the 1990s, the complexity of transactions has increased and the legalisation of problem solving has intensified. We now recognize, too, that the binary representation of the state directing its intervention at an industry or individual (at the

Cambridge Mass, 1987) most successfully employs this wider framework, applying it to four public law case studies.

Eg D Bayley and C Shearing "The Future of Policing" (1996) 30 Law \& Soc'y Rev 585. 
behest of competing lobbyists) is an inadequate representation of the contours of governance.

The indications from political science are that patterns of governance are diverse, and vary for individual economic sectors. ${ }^{17}$ This is a significant hypothesis for the present discussion because the structure of the consumer service sector in Japan is considerably removed from the standard depiction of Japanese industry. The flagships of manufacturing and their affiliated trading companies and banks have always been somewhat unrepresentative of the wider economy; most Japanese work in small and medium sized enterprises. Keywords in financial press of the 1990s are cost cutting, retrenchment and outsourcing. Larger institutions are gradually dismantling growth period employment practices such as lifetime employment, seniority-linked remuneration and in-house training of generalists. Employee responses to the changing climate include dokuritsu (setting up an independent business), joining an FC (buying a franchise outlet), and semon shitauke (becoming a specialist supplier, often to a former employer). Overall unemployment rates in the 1990s have remained fairly stable, in part because of underemployment at large corporations, but also because the so-called new service sector has also absorbed voluntarily and involuntarily retrenched middle managers, younger white collar workers, and university graduates failing to secure jobs with large companies. Employment in the service sector increased by about $15 \%$ between 1989 and $1994 .^{18}$

More than a third of Japan's service business has been established after 1980. They now produce about $80 \%$ of the value of the retail sector output and about $25 \%$ of the value of Japan's manufacturing sector, but are growing much faster than either. Figures for 1989 to 1994 show a growth rate of $46.9 \%$ for domestic services, in comparison with $20.3 \%$ for retailing and $0.5 \%$ for manufacturing. ${ }^{19}$ The most profitable service for the same period was pachinko (adult pinball gambling). This is hardly surprising - casual empiricism confirms that pachinko parlors are springing up everywhere. Some estimates suggest that the industry has doubled in size over the last 5 years and is now worth 30 trillion yen, or $40 \%$ of the national budget. ${ }^{20}$ Some way behind pachinko follow services provided by Japanese style inns; advertising agencies; timber construction; computer software; and industrial equipment leasing. Of themselves, however, the figures, are not really indicative of the

17 See above $\mathrm{n} 3$.

18 Chushokigyocho [Small and Medium Sized Business Agency] (ed) Nyu sabisugyo hakusho [New Service Industry White Paper] (Nikkan Kogyo Shimbunsha, Tokyo, 1996) 198.

19 Above n 18, 202, using figures from the Ministry of International Trade and Industry statistics (Shogyo tokeichosa and Kogyo tokeichosa).

20 Teikoku Data Bank figures, quoted in Mainichi Shimbun, "Shakeout Seen Coming as Pachinko Wars Rage" (20/1/1997) 14. 
volatility or the future outlook of individual service businesses. Pachinko, for example, is expanding rapidly as operators transform grubby pinball arcades into entertainment complexes appealing more to the female market. However, the effects of Japan's "bubble period" expansion are also evident. While 130 parlors opened in Japan last year, 57 pachiko businesses also declared bankruptcy.

Japan's service businesses are almost evenly divided between those targeting individual consumers $(46.2 \%)$ and those providing services for industry $(43.9 \%) .{ }^{21}$ In the personal service sector, however, the overwhelming number of providers (82.2\%) are individuals rather than incorporated entities. Even in the services for industry sector, $41 \%$ of service providers are individuals, and of the remaining $58 \%$ which are legal entities, only half are incorporated as companies. ${ }^{22}$ Calculated by size (ie the number of outlets and employees) the largest service providers to individuals are beauty salons; personal tutors; esthetic salons providing body and face care; laundry services; Japanese style inns; driving schools; recreation facilities; parking lots; machinery repairs and photographers. ${ }^{23}$ The largest service providers to industry are: timber construction services; miscellaneous specialist services; accounting and tax services; Agriculture, Forestry and Fisheries Cooperatives; information services; leasing; administrative and judicial scriveners; advertising; and law office and patent office services. ${ }^{24}$ In each case these represent older, established business types, but the government figures are selective. Entertainment and gambling services such as pachinko, which is classified and regulated as a business affecting public morals (fuzoku eigyo) are included, but (unless it constitutes a 'miscellaneous' service) the extensive and institutionalised sex industry is not.

Government predictions about the sectors in which new services are expected to expand are similarly conservative. ${ }^{25}$ Over the last two to three years, however, the most noticeable growth has been in newer services. The Small and Medium Sized Business Agency defines new service businesses as those that either provide new services or that have segmented existing services by giving them a new institutional form (eg chain stores, franchising); those which have developed new forms of service delivery; services which use new forms of technology; services which trade on internationalisation (movement of people and goods); and services which consolidate a number of elements to create new value added. ${ }^{26}$ Examples

21 Above n 18, 198.

22 Above n 18, 199.

23 Above n 18, 176.

Above n 18, 178.

Above n 18, 11. 
include house cleaning services tailored for elderly people; a franchise chain of quick massage services; retirement homes which allow pets; baby-sitting services which take and collect children from day care; middle and high school tutoring services that provide materials via fax; temporary office staff services offering internship placements to female college graduates; personal computer leasing; sporting goods buy back and recycle services; and e-mail translation services. 27

Many of the new services replicate patterns of consumption in other industrialised economies, such as the growth in personalised health and beauty services. Others represent the institutionalisation and expansion of traditional services such as home tutoring and English instruction. Many respond to the aging population (private aged care and home nursing) and to the needs of working women (child care, home cleaning). Some trade on instability in the labour market and the strong Japanese tradition of obtaining qualifications (computer software courses, bookkeeping and accounting qualifications, and certification in everything from landscape gardening to calligraphy).

Despite a tendency to see new service industry growth on an ever upward trend, it is more likely that these service businesses suffer from the same mixed fates as most small businesses. For every new operation that opens there is another that closes, due to lack of credit, inexperience, or inability to predict and respond to consumer preferences. ${ }^{28}$

\section{ANATOMY OF CONSUMER PROBLEMS}

When consumers purchase services from this sector they face the perennial problems of asymmetry of information and experience, as well as the danger that the service provider will engage in sharp practice, be unable to provide the service promised, get into financial difficulty, or simply go out of business and disappear. Citizens' advice bureaus and consumer complaints centres began to register significant numbers of complaints about service contracts from around 1990 onwards. ${ }^{29}$

Analysis of computer records for consumer complaints in 1995 by the Japan Federation of Bar Associations identified four main problem areas: esthetic services; foreign language schools; home tutoring services; and university entrance prep schools. In each case the number of complaints and inquiries recorded by local government consumer centres and citizens' advice bureaus quadrupled between 1986 and 1992, with a dramatic increase after

Above n 18, 186.

See generally the figures for closures in above $n 18$.

See generally, Nichibenren Shohishamodai Taisaku Iinkai Japanese Federation of Bar Associations Consumer Issues Committee] (ed) Keizokuteki sabisu torihiki: shoshisha toraburu kaiketsusaku [Continuing Service Transactions: Strategies for Resolving Consumer Problems] (1995) 32 NBL Bessatsu 2. 
$1990 .{ }^{30}$ Consumer Centre staff estimate that complaints received represent about $4 \%$ of the actual incidence of problems. This rule of thumb contemplates the difficulty of getting though on a limited number of phone lines, the limits to staffing and the reality that the centres offer no enforcement mechanisms. ${ }^{31}$ This may account for the pattern of establishing consumer service and Bar Association "hotlines" for problem areas such as esthetic services, in an effort to better gauge the extent of the problem.

Consumer service contracts extend across a wide range of businesses, but they also share some characteristics. The first is some ambiguity about the content and the quality of the service to be provided. In most cases the service is highly personalised, and its efficacy depends in part on a subjective assessment by the consumer. Typically there is a gap between what was promised or advertised, and what the consumer understands that they are receiving. Whether the gap arises because of a breach of contract or failure to perform according to the terms is often difficult to assess.

Analysed from a legal viewpoint, consumer complaints cluster around issues of disclosure, formation, performance and termination. Often the problem is combined with the sales method. Recent problems include telephone sales of qualifications, where a unsolicited sales call to the consumer's home or office elicits an oral response such as "Yes" or "Thank you" (but meaning "No thank you"), which the service provider subsequently treats as assent to a contract and the basis for demanding payment. Door to door sales, on the other hand, account for more than half of the complaints in relation to home tutoring in the Japan Federation of Bar Association's study.

From the service providers' point of view, the risk of consumer dissatisfaction is substantially lessened by using a detailed, standard form contract which discourages complaints. For a nation with a supposed aversion to contracts in writing, these consumer contracts represent masterpieces of restrictive drafting. In most cases the contract is to be performed in instalments over time, but all fees are payable in advance and are subject to a no refunds clause.

In the past tutoring was paid for monthly, but the shift to payment in advance has been accelerated by linking the main agreement to a credit contract with a third party credit provider. As with any credit arrangement, when repayments to the credit company are made in instalments, the consumer has the feeling that the payment for the service is taking place monthly, when in fact the contract price has been paid in advance. Problems arise when the service provider goes bankrupt or when the consumer is no longer able to receive the

30 The figures for individual centres in Tokyo and regional centres vary, but total around 10,000 complaints in this category: see above $\mathrm{n} 29$.

31 Personal communication. 
service, but the credit obligation remains. The credit company may direct the consumer to continue with the contract at another location, and the consumer may find this inconvenient or inappropriate, or the original service may simply be inadequate and the consumer may want to terminate the agreement. The question in most cases is whether the consumer can terminate the agreement and receive a refund and/or damages. The answer is by no means clear. It depends on which rules are invoked from which of several interrelated universes: the transactional relationship between the parties, with or without intervention by lawyers; the self-regulatory Codes of Conduct and model contracts devised by the bureaucracy and industry representatives; or the judicial remedies of the Civil Code.

\section{THE FRAMEWORK FOR JURIDICAL INTERVENTION}

Japan has no general consumer protection legislation. Many lawyers argue that the absence is not accidental - that it reflects a political choice to privilege industry interests, especially those of manufacturing, during the 1960s and 1970s. Legislative controls on merchant behaviour in consumer transactions remain piecemeal and indirect.

At one level merchant behaviour is constrained by the Antimonopoly Law (AML), monitored and enforced by the Japan Fair Trade Commission (JFTC), and the Unfair Competition Prevention Law. ${ }^{32}$ In practice, neither law offers effective remedies to consumers affected by unfair trading. Both focus primarily on acts that harm commercial competitors, and neither law directly invalidates contracts which incorporate provisions found to contravene the legislation. Although article 45(1) of the AML allows complainants to request the JFTC to report and take appropriate measures in response to a complaint, the decision to do so is purely discretionary. The JFTC to date has been unwilling to initiate action based on consumer complaints, ${ }^{33}$ and attempts to compel them to change decisions directly affecting consumer interests have generally been unsuccessful, in part because Japanese courts interpret standing requirements strictly. ${ }^{34}$ As Matsumoto points out, the only remedial route at this level for consumers is to claim damages for the tort liability of the JFTC as a state agency under the State Compensation Law. ${ }^{35}$ Again, precedent to date

32 Law No 47, 1993.

33 T Matsumoto "EC Directive on Unfair Terms in Consumer Contract and Japan: Does the Japanese Law Meet the Standards Set By the Directive?" (1994) 2 Consumer LJ 141. Note, however, the JFTC warning to the esthetic industry in 1987 about misleading advertising in relation to weight loss: above n 29,7 .

34 See eg Supreme Court (14 March 1978) 32 Minshu 21 (denying a consumer group standing to challenge an administrative disposition by the JFTC regarding fruit juice pricing).

Law No 125, 1947. 
suggests that the evidentiary burden - the requirement to show that the loss would not have occurred but for the discretionary decision taken - generally makes this unfeasible. ${ }^{36}$

Government intervention in consumer transactions has tended to be reactive and take the form of other special legislative provisions which invalidate 'unfair' provisions in consumer contracts. ${ }^{37}$ In many cases, this special legislation is enacted outside the Civil Code in order to 'siphon off' litigation in problem areas. ${ }^{38}$ This pattern accounts for the enactment of the Door to Door Sales Law; the Instalment Sales Law; and more recent interventions such as the 1992 Law Regulating Membership for Golf Courses. ${ }^{39}$

The genesis of the Product Liability Law, (PL Law) was somewhat different. ${ }^{40}$ The PL Law is regarded by some commentators as the first stage in the emergence of a new wave of consumer protection, influenced particularly by legal developments in the EU. The passage of the PL Law was vigorously opposed by manufacturers, on the grounds that it was likely lead to an explosion of product liability litigation along the lines of the American experience. This, industry argued, would reduce consumer welfare by adding to production costs. Nothing of the kind has happened so far. The brief core provisions of the PL law create a no-fault scheme of liability in which consumers need only show that physical and/or economic harm resulted from use of a (defective) product, with the court inferring causation. The legislation itself does not represent a major doctrinal departure from case law to this point. Nor are judges in Japan's non-jury system expected to depart radically from their practice of awarding relatively low damages, and like other civil law jurisdictions Japan has no tradition of awarding punitive damages. Procedurally, the PL Law is also hedged with a scheme of mediation and conciliation centres endorsed by a variety of Government agencies, which seek to settle consumer claims without recourse to the courts. In early 1997, for example, the consumer policy section chief of the Ministry of International Trade and Industry (MITI) reiterated the Ministry's stated policy of

36 See eg Tokyo District Court (22 April 1992) 1431 Hanrei Jiho 72, cited in Matsumoto, above n 33.

37 See eg arts 9 and 30 of the House Lease and Land Lease Law (providing notice periods in favour of consumers); art 5 of the Instalment Sales Law (limiting the damages claimable from consumers in case of contract cancellation); art 6 of the same law (applying a cooling off period in favour of consumers).

38 L Nottage "Form and Substance in US, English, New Zealand and Japanese Law: A Framework for Better Comparisons of Development in the Law of Unfair Contracts" (1996) 26 VUWLR 247, 280 (quoting Nakaya).

39 Respectively, Law No 57, 1976; Law No 159, 1961; Law No 53, 1992.

40 Law No 85, 1994. See generally M Kato Seizobutsu Sekininho Soran [Survey of Product Liability Law] (Shojihomukenkyukai, Tokyo, 1994). 
continued "positive support of speedy, simplified dispute resolution by third parties outside courts, using the so-called PL centres".41

At the local level, there are a cluster of ordinances passed by preferectural and local assemblies that specifically target fair trading in consumer transactions and provide, inter alia, for cooling off periods. There is little indication in the legal literature that these have anything more than hortatory effect. ${ }^{42}$ None of the national 'special' laws is directly applicable to consumer service contracts, except insofar as these are combined with the sale of products. For the most part, legal complaints about consumer services have to be argued within the framework of the Civil Code.

In the world of the Civil Code, continuing contracts for the provision of services are contracts of quasi mandate (article 656). They are distinguished from a contract of mandate, which is for the performance of a legal act (article 643), and from a sub contract for the performance of work, where the purpose of the contract is not only the work performed but also production of a defined outcome (eg construction, cleaning: article 632). In principle, a contract of quasi mandate can be terminated at the option of either party at any time (article 651(1)); but where the termination unfavorably affects the other party, the terminating party has a obligation to pay damages for loss sustained by the other party (article 651(2)). The exception to the rule is where termination is sought for an unavoidable reason; the rationale being that contracts for mandate and quasi mandate depend on the existence of a trust relationship between the parties, and where this has broken down it is illogical to treat the contract as binding. ${ }^{43}$ The right to claim for damages for termination of these kinds of contracts has been interpreted as being limited to the reliance damage sustained because of sudden termination, not the full value of the unperformed part of the contract. In most cases this should equate to the value of the appointment or part of the performance occurring immediately after the notice to terminate is received. ${ }^{44}$

Of course, contract parties are free to contract out of provisions of the Civil Code that are not mandatory. Here, the doctrinal question impacting on consumer choice is whether, where there is a standard form contract provision that expressly prohibits early termination, consumers should be taken to have waived their right to terminate the services

41 F Ota "Tsushosangyosho no shoshisha gyosei no tenbo [Future Directions for MITI's consumer administration]" (1997) 608 NBL 19.

42 See the example analysed by Nottage, above n 38, 286; and "Shoshisha torihiki no tekiseika ni mukete [Toward the Regulation of Consumer Transactions: 15th Annual Report of the Consumer Policy Section, Citizen's Lifestyle Commission, December 1996]" (1997) 608 NBL 61.

43 Above n 29, 14.

44 Cf the approach in commercial continuing contracts: Taylor, above $\mathrm{n} 11$. 
contract before the full term expires. The scholarly and administrative consensus appears to be that such provisions do not extinguish the right to terminate the contract, but equally do not excuse the obligation to pay damages. At the same time, they do not give rise to an obligation to refund monies already paid under the contract. ${ }^{45}$

Where the services are provided under a standard form consumer contract, the basis for claiming a right to terminate and the right to receive a refund or claim damages has to be found elsewhere. In practice, claims often proceed in tort, but here the two main contract strategies are considered. One is to terminate on the basis of breach by the service provider. Typically this will be possible where the service provider goes bankrupt or is unable to continue providing the service, eg because of a change of business location. Alternatively the claim may turn on the quality of the service provided, and this will depend on the nature of the explanation and advertising received at the time that the contract was made. ${ }^{46}$

Secondly, where it is difficult to establish a clear breach, the consumer may assert the right to terminate based on the jurisprudence of the general provisions of the Civil Code: breach of public policy and good morals (article 90); good faith (article 1(2)); or abuse of right (article 1(3)). Conceptually these are separate grounds of action; but courts, and especially plaintiff attorneys, frequently use the concepts interchangeably.

If a consumer contract contravenes public policy and good morals, it will be void. Accordingly, courts are relatively reluctant to recognize this claim, but there is case law in relation to standard form contracts, for example, that finds that an unreasonable limitation on the amount of damages claimable under the contract would contravene the mandatory public policy requirement of the Civil Code. ${ }^{47}$

This jurisprudence could be used to combat the practice of withholding refunds of prepaid contract monies on the ground that they constituted a pre-estimate of damages for contract cancellation. The problem with asserting this in the past was that there was no standard against which the amount being withheld could be assessed. As the Japan Federation of Bar Associations now points out, the adjustment of model contracts in the four 'problem' sectors identified above now provides some yardsticks because the model

45 Above n 29, 16.

46 See eg Osaka District Court (4 February 1993) 1481 Hanji 14; and the commentary by H Hirano in A Morishima and S Itoh (eds) Shohisha torihiki hanrei hyakusen [A Hundred Selected Consumer Cases] (November 1995) 135 Bessatsu Jurisuto 118.

47 See T Matsumoto Shohishakeiyaku ni okeru fukoseijokono kisei-EU to nihon no hikaku [The Regulation of Unfair Terms in Consumer Contracts - The EC and Japan Compared], in unpublished Conference Proceedings "EU-Japan Legal Dialogue: Contract" (November 21 and 22 1996, Kyoto Comparative Law Center). 
contracts stipulate upper limits for contract cancellation charges. ${ }^{48}$ Attempts to withhold amounts greater than those stipulated in the model contracts can be argued to be void for public policy and good morals on the basis that they offend against the reasonable contract practices of the industry. ${ }^{49}$

A broader ground for challenging consumer contract fairness is the doctrine of good faith. This has been applied by Japanese courts in a number of ways. The most recent significant cases for consumer problems are the so-called Dial Q2 (or fee for call telephone numbers providing information services including telephone sex). In Japan, as elsewhere, one group of cases concerns the liability of the householder to pay charges incurred without their permission, usually by children. Here, the standard form contracts with telephone company NTT typically imposed liability on the householder who was party to the contract. Despite the wording of such clauses, Japanese courts in a series of decisions have found that, where the amount in issue is exceedingly high, it would be unreasonable and therefore a breach of good faith to allow the telephone company to enforce the claim against the householder. ${ }^{50}$

A further subset of this ground is unavoidable reason, such as long term illness or a change of residence, which viewed objectively would make continuation of the contract extremely difficult. At least one view also holds that in contracts where the basis of the contract is confidence in the service provider, such as contracts for educational services, loss of confidence by the consumer may of itself be sufficient to amount to a unavoidable reason for termination. ${ }^{51}$

Some case law and scholarly writing also suggests that the neighboring doctrine of abuse of right can also be mobilized to assert a right to terminate, although this is also contested. Where it has been used, it has often been grounded in a failure to disclose important information, or a failure to perform a duty to explain. An interesting, if unusual, example is the decision of the Nagoya District Court, which held that the plaintiff was entitled to recover part of the $5,896,000$ Yen $(N Z \$ 75,000)$ paid to a Buddhist priest in order to cure the plaintiff's child of natural deafness. ${ }^{52}$ The court held that the treatment itself did

48 In the case of esthetic treatments, $10 \%$ of the balance of the contract amount, or within JPY 20,000; in the case of prep schools, within one months tuition fee; in the case of English language schools, $20 \%$ of the balance of the contract amount or JPY 10,000 . 
not breach public policy and good morals; but that the failure to inform the parent that a cure was unlikely after the promised year had elapsed and the child had been treated 700 times "exceeded the bounds of what could be deemed socially acceptable", and that the balance of the contract was void for abuse of right. ${ }^{53}$

Thus the core remedies for consumer contract problems currently have to be extrapolated from a Civil Code which, while it contemplates continuing contracts for the provision of services, provides no customised principles for dealing with the problems of contractual disclosure in consumer settings or early termination. Uchida argues the general provisions of the Japanese Civil Code have been singularly important in developing case law and jurisprudence to bridge the gap between the framework of the Civil Code and the social expectations and immanent norms that attach to the performance and resolution of problems in continuing contracts. ${ }^{54}$ Matsumoto, on the other hand, points out that the courts to date have not usually distinguished between standard form contracts and those bargained for by the parties. The result, he suggests, is that courts have tended to read down the scope of some boiler plate clauses (reibun) in the kind of pre-printed contracts purchased at stationery stores regarding residential leases or compromises made after a traffic accident, on the basis that one or other party did not consent to the content. One the whole, however, he suggests that courts have been comparatively willing to enforce standard form contracts without inquiring into the terms. ${ }^{55}$ Perhaps for this reason, Omura argues that utility of the public policy and good morals provision of the Code and in particular the use of the concept of abuse of right needs to be reinvigorated as a control on standard form contracts in consumer settings. .56

Japan's general clause jurisprudence on consumer contracting is well-developed, but it suffers from the obvious drawbacks of case law as a remedial framework. Because the judicial response is reactive to particular problems, the resulting case law is neither necessarily consistent or complete. More importantly, juridical intervention has to be activated by filing suit, which - until the revisions to the Code of Civil Procedure discussed below - effectively insulated service providers from consumer claims.

53 Itoh, above $\mathrm{n}$ 52, 124.

54 T Uchida, above n 11, 223ff; T Uchida "Gendai keiyakuhô no aratana tenkai to ippanjoko [New Developments in Contemporary Contract Law and General Clauses]" (1994) NBL Nos 514-517.

55 Matsumoto, above $n 47$.

56 A Omura Kojoryozoku to keiyaku seigi [Public Policy, Good Morals and Contract Justice] (Tokyo, Yuhikaku, 1995). 


\section{REGULATION THROUGH BUREAUCRATIC INTERVENTION}

Up to this point, the framework of regulation and relationships looks fairly clear: consumers and service providers transact, and where there is conflict, the law provides general contract principles and case law jurisprudence. In fact, the relevant policy network is crowded and contentious. For the service providers, the responsible nominate agency is the MITI's Small and Medium Sized Business Agency (Chushokigyocho) and the core legal vehicle for government policy is the Basic Law on Small and Medium Sized Enterprises, ${ }^{57}$ around which constellate more than 30 other special laws enacted to support and restructure small business. The Agency's 1996 White Paper also proposes a further legislative package of incentives and protections for these businesses, but there are no indications of legislative movement in this direction for the present. ${ }^{58}$

In the consumer service sector the policy players include the Service Industry Section of the Ministry of International Trade and Industry; the Economic Planning Agency; local government; government and local government services such as the Citizen Life Centres (Kokumin Seikatsu Senta) and the Consumer Welfare Bureaus (Shohisha Seikatsu Senta); the Japan Federation of Bar Associations; industry associations; government/industry selfregulatory bodies; credit providers; academic and policy advisors; and consumer groups.

\section{A Applying Lateral Pressure: Tsutatsu Gyosei}

When consumer service contract problems began to surface (or began to be acknowledged) in the mid-80s, MITI responded with the bureaucratic staple, the Research Group Report. ${ }^{59}$ During the late 1980s, amendments to both the Door to Door Sales Law and the Installment Sales Law were debated and local governments, consumer groups and Bar Associations formed a range of study groups and hotlines to deal with the burgeoning number of complaints about service contracts relating to esthetic services and cram schools.

MITI then used administrative guidance (gyosei shido) to the credit industry in 1992, requesting credit providers to carry out stricter investigation and approval before providing consumer credit facilities to new chain stores or retail affiliates in sectors providing continuing consumer services ${ }^{60}$ This was followed with a formal administrative circular (tsutatsu) to the Japan Credit Industry Association and the National Credit Association which directed that: ${ }^{61}$

57 Law No 154, 1961.

58 Above n 18, 172.

59 Yakumutorihikitoi kenkykai hokokusho (May 1986): see above n 29, 7.

60 Above n 29, 7.

61 Above n 29, 23. 
In a case where a so-called esthetic salon, foreign language conversations school, entrance exam school or home tutoring service is an affiliate or chain store of [a company] providing continuing services and becomes unable to do so either because of bankruptcy or for other reasons, [you are required to] immediately cease requests for payment to consumer. Note that this requirement can be substituted with an arrangement where the same service as that stipulated in the contract between the consumer and chain store or affiliate can be provided through other means and the consumer consents to this.

Direction by means of administrative circulars is a standard channel through which administrative bodies direct subordinate bodies over which they have a regulatory jurisdiction. Of themselves circulars are not a source of law; they are binding within the administration, but have no legal force in relation to citizens or the courts. They do, however, have a de facto effect on third party conduct because one can expect the law to be applied in line with the circular unless there is a foreseeable challenge or dispute about the content.

In this case MITI had a dual problem. On the one hand, it sought to direct credit providers to act as a preemptive, lateral control on service outlets. On the other hand, the subsequent tsutatsu was necessary because credit providers themselves were exacerbating consumer conflicts by insisting that the credit contract was entirely separate from the service contract, and therefore valid, regardless of any problems the consumer was having with the service provider. As the tsutatsu recognizes and lawyers point out, credit companies were (and are) often instrumental in pressuring the consumer to accept a substitute service elsewhere and preserve the credit contract intact.

\section{B Directed 'Self-Regulation'}

Between 1988 and 1995, each of the 'problem' sectors established one or more industry associations, partly at the direction of MITI and partly in anticipation of new legislative controls being applied to them. This kind of directed 'self-regulation' is ubiquitous in Japan, but not uniquely so. ${ }^{62}$ In many Japanese industries, bureaucratic leverage is sustained through the legislative requirement that commercial actors in the industry adopt and use a standard form contract approved by the relevant Ministry, either requiring prior permission (ninka) or requiring subsequent reporting (todokede). ${ }^{63}$ In practice this takes two

62 Cf eg N Tollemache "Taking the Ombudsman Concept into the Private Sector: Notes on the Banking Ombudsman Scheme in New Zealand" (1996) 26 VUWLR 233.

63 Matsumoto, above n 47, quotes the example of the Telecommunications Law (Law No 87, 1980) which requires primary telecommunications providers to have their standard form contracts approved in advance by the Ministry for Posts and Telecommunications (art 31(1)) but allows special secondary providers to simply the content of theirs (art 31(5)) and exempts general secondary providers. 
forms. For one group of industries, whether the standard form contract is approved at the ninka or todokede stage, it is mandatory. ${ }^{64}$ Matsumoto notes that, though consumer groups may be consulted in the formulation of these contracts, at the end of the day they are basically drafted by the relevant Ministry and announced by the responsible regulatory agency ${ }^{65}$ In contrast to this, a second type of standard form contract is usually developed for industries where there is no legislative basis for regulating entry to the industry or contracts used within it. In this case, the bureaucracy uses administrative guidance to encourage industry associations to draft a standard form contract and recommend the adoption of this 'model contract' by association members. These contracts are then examined and critiqued by bureaucrats, by consumer organisations, and by the National Life Council (Kokumin Seikatsu Shingikai); and in a number of cases have been revised as a result. ${ }^{66}$

In the service sector examples discussed above, none of the 'problem' service providers had (or were required to have) approved contracts. MITI took the view that 'selfregulation' was preferable to specialised legislation, and effected this through developing a series of 'model contracts' with the industry associations between 1992 and $1994 .{ }^{67}$

The new model contracts are intended to operate as de facto legislation. In the case of the esthetic industry example, the contract is annotated with instructions for operators about what each clause means and what measures they should take when explaining the contract to consumers. ${ }^{68}$ The model contracts for consumers are supplemented with a series of industry regulations and guidelines developed by each industry association, that seek to restrain illegal or inappropriate acts by operators. ${ }^{69}$

64 Examples include the Travel Industry Law (Law No 239) arts 12-2 and 12-3; the Home Delivery Service Standard Form Contract and the Transport Removal Contract under the Road Transport Law (Law No 183, 1951) arts 62 and 11; the Standard Trunkroom (Storage Facility) Contract under the Warehousing Industry Law (Law No 121, 1956) art 8.

65 Above $\mathrm{n} 47$.

66 The latter, under the aegis of the Prime Minister's Office, has reviewed standardised consumer contracts in a range of industries, including life insurance, travel, marriage and funeral services, consumer banking, auto sales, credit cards, golf clubs (1981); transport of goods, hotels, warehousing, banking and non-life insurance (1984); and old age homes, sports clubs, resort clubs and household good rentals (1988): see Matsumoto, above $n 33$.

67 Reproduced in above $\mathrm{n} 29$.

Above n 29, 121.

69 In the esthetic industry, this takes the form of a standard contract intended to bind members of wither the Japan Estheticians Association and the Japan Esthetic Industry Association: above $\mathrm{n}$ 29, 132. The Standard Agreement prohibits, inter alia, acts such as: claims about results which have not basis in science and would not normally be possible; comparative advertising directed at other salons or products; use of fictional examples or inaccurate data; use of public figures' 


\section{LAWYERS AS AGENTS AND LEGISLATIVE LOBBYISTS}

The Japan Federation of Bar Associations' response to these bureaucratic initiatives has been largely negative. While lawyers concede that the model contracts represent an improvement on past practice, they are critical of many of the provisions. The contracts, for example, do concede the de facto right of consumers to terminate early, but constrain this by imposing a prescribed fee.

Lawyers argue, too, that the model contract/industry guideline model does not resolve one of the core consumer issues - the right to use the breach of the consumer service contract as the basis for termination (or defending non-performance) of the consumer credit contract. Thus the Japan Federation of Bar Association stance is fundamentally to lobby for, and support the introduction of, specialist legislation.

The 1996 Report from the National Life Council goes further, arguing that specialist legislation is required urgently. ${ }^{70}$ The Committee behind the report includes both academic and practising lawyers. One of the powerful 'push' factors for the report is clearly the introduction of the EU Directive on Unfair Consumer Contract Terms. Consumer law specialists such as Matsumoto suggest that, ideally, Japanese legislation would go further than the Directive, by covering the pre-formation stage of consumer contracting as well as monitoring the fairness of contract provisions. ${ }^{71}$

The rationale for legislative intervention in this report, however, is clearly economic efficiency. The Economic Planning Agency argues that the current state of the case law is inadequate because it is an unreliable predictor of outcomes in individual cases, and that there would be benefit for both consumers and industry operators in articulating the situations in which good faith; public policy and abuse of rights are likely to be infringed by service contract behaviour. ${ }^{72}$ The report expresses this as the need to make the civil law "rules" clear - a formula favored by economic commentators, but somewhat at odds with the trend within contract law worldwide to move beyond neoclassical rules to the imposition of "standards".

photographs without permission; claims about facilities that are open to misinterpretation; use of doctored photographs; acts which conflict, or may conflict with regulatory laws covering pharmacists, acupuncture practitioners, shiatsu practitioners, etc.

70 "Shoshisha torihiki no tekiseika ni mukete [Toward the Regulation of Consumer Transactions]", above n 42.

71 Matsumoto, above n 47, 13.

72 "Shoshisha torijiki no tekiseika ni mukete [Toward the Regulation of Consumer Transactions]", above n 42. 
If the proposed legislation is seen as symbolic or preemptive - signaling a sea-change in the policy environment - then we are likely to see something like the pattern emerging in relation to product liability, where policy network players protect their interests in different ways. Thus MITI may move to coerce or cajole alternative dispute resolution to defuse potential litigation; manufacturers insure and pressure their suppliers to do likewise; companies with standard form contracts redraft and review their risk allocation; lawyers study up in preparation for invoking the legislation in negotiation or in court; and consumer groups receive an additional lever in their repertoire of political and legal leverage.

The Economic Planning Agency, however, views the legislative proposal much more instrumentally - cutting through the confusion of case law and operating as a template for rational planning. This is unreflexive positivism, which shares some of the MITI distrust of, and distaste for, the court-based dispute resolution. However, if we look at drafting to date, Japanese legislation does not tend toward prescriptive lists, but rather allows ample room for bureaucratic and judicial discretion. The EU experience, too, tends to show that it is difficult to precisely define unfair contract behaviour in advance. Judicial intervention cannot be easily cut out of the governance matrix, in part because it is required for resolving hard cases, but also because self-governing networks draw on judicial norms and de facto rules in the development of non-legal control devices. In a sense, the self-governing network is predicated on the availability and operation of formal legal adjudication at the outer perimeter, to monitor and enforce internal rules and agreements.

Part of the Japanese lawyers' agenda is also professionally self-serving. It is based on a fairly strong desire to get consumers out of the clutches of the industry and their bureaucratic mentors and into a forum where the consumer has legal representation and where (new) legal rules can be applied with transparency and uniformity. Although the Japan Federation of Bar Associations does not allude to it in their 1995 report, the newly revised Code of Civil Procedure is likely to be important here. The stated rationale for the overhaul of the Code is to improve citizen access to civil proceedings and to rationalize some of the time and cost barriers. The Code revisions create for the first time a small claims jurisdiction for Japanese courts; the likely destination for consumer service contract claims. ${ }^{73}$ Another related change is the recent increase in the number of candidates permitted to pass the National Bar Exam. Though the formal increase in the numbers was designed to yield more public prosecutors, the likely outcome is more attorneys, and the Federation of Bar Associations has been vocal about its concerns about how the demographic change is

73 See eg Minjisoshoho shinkyu taisho jobun [Comparative Tables of Original and Revised Civil Procedure Code Provisions] (1996) 1096 Jurisuto Bessatsu Furoku. 
likely to affect legal practice. Consumer transactions seem poised to become a domestic growth area for these reasons also.

\section{CONCLUSION: DEREGULATION AND RESISTANCE}

What is really at stake here is not the absence or introduction of legislation as such, but the balance of power and influence within the consumer policy network, and the struggle over the degree to which the policy domain becomes legalised. MITI implicitly recognises this when its Policy Office Consumer Economics Section chief primly concluded in a leading law journal that: "What is required is not simply measures based on law, but greater personal efforts to ensure the advance of consumer enlightenment and the adoption of reasonable practices by private corporations". ${ }^{74}$ The telling factor is not so much the bureaucratic homily urging consumers and corporations to try harder, but that the same journal issue features the 1996 National Life Council report highlighting consumer service contract problems, and that this is flanked by a number of essays by leading lawyers calling for a consumer contracts law. ${ }^{75}$ The MITI essay, on the other hand, completely ignores consumer service contracts and nominates the key areas for 1997 as (i) the 1996 revisions to the Door to Door Sales Law; (ii) plans to rationalize the labeling scheme for household products; and (iii) the implementation of the PL Law.

Part of MITI's apparent unwillingness to engage in the consumer contract debate can be attributed to jurisdictional turf protection. In support of its governmentally-guided 'selfregulation' scheme, MITI is now also invoking the rhetoric of deregulation: "In this deregulatory climate ... legislation (is simply inappropriate)". ${ }^{76}$ This stance is easily rebutted by pointing to the theory and practice of deregulation as reregulation. ${ }^{77}$ The theoretical debate in Japan, at least as reflected in the legal literature reviewed here, is still at a threshold stage. What we can discern is that the regulatory domain is being contested and that the contours are shifting, and likely to shift further, perhaps toward formal "legal" forms and forums, but within a matrix of multiple players and other techniques of governance. ${ }^{78}$

74 Above n 41, 18.

75 "Shoshisha torihiki o tekiseika ni mukete [Toward the Regulation of Consumer Transactions]", above n 43; S Ochiai, "Shohisha keiyaku ho no hitsuyosei ni tsuite [The Need for a Consumer Contracts Law]" (1997) 608 NBL 3.

76 Above n 41, 18.

77 See eg OECD, above n 1.

78 Cf Haley's argument about the relative dominance of non-legal informality in Japan: above $n 9$. 
The important question, posed recently by Cotterrell, is: what do we mean by legal? ${ }^{79}$ Law and economics perspectives are currently influential outside (but not accepted within) Japan, and tend to underpin views that the appropriate role for law and legal forums in a deregulatory climate is to function as instruments of political and economic policy. Many legal theorists, on the other hand, increasingly emphasise the need to view law as necessarily linked to and proceeding from community norms (leaving aside the vexed questions of whose norms, how these are distilled, and what judges do with them). Elements of both sets of assumptions are evident in the writing on consumer service contracts in Japan at present. What this snapshot suggests is that, as the question of how to curb excesses of power in a deregulated environment governed by multiple agents becomes more acute in Japan, consumer contract governance will change, and with it the utility of our current theories of how law operates in Japan.

79 R Cotterrell Law's Community (Clarendon Press, Oxford, 1995). 